ТА ІНЖЕНЕРІЯ

Удк 61:007:004:681.31

DOI: http://dx.doi.Org/10.11603/mie.1996-1960.2016.4.7056

\title{
ТЕХНОЛОГІЧНІ АСПЕКТИ КІЛЬКІСНОГО ОЦІНЮВАННЯ ЕФЕКТИВНОСТІ ІНТЕГРАЛЬНОЇ РОБОТИ ІНФОРМАЦІЙНИХ СИСТЕМ
}

Л. Ю. Бабінцева

Національна медична академія післядипломної освіти імені П. Л. Шупика

\begin{abstract}
Розглянуто питання ролі процедур виявлення нової інформації в умовах стрімкого збільшення кількості неструктурованих даних. Представлено характеристики інтеграції інформаційних систем, що фрункціонують в єдиному інформаційному просторі. Визначено, що оцінювання ефективності інтеграції інформаційних систем в одній проблемній області потребує застосування двох груп коефіцієнтів - узагальнюючих і технологічних; вибір споріднених інформаційних систем має здійснюватися за допомогою коефіцієнтів емерджентності.
\end{abstract}

Ключові слова: інформаційні технології, єдиний інформаційний простір, якість надання медичної допомоги, єдина інформаційна система охорони здоров'я, комплементарність інформаційних систем, конгруентність інформаційної системи, емерджентність інформаційних систем.

\section{ТЕХНОЛОГИЧЕСКИЕ АСПЕКТЫ КОЛИЧЕСТВЕННОЙ ОЦЕНКИ ЭФФЕКТИВНОСТИ ИНТЕГРАЛЬНОЙ РАБОТЫ ИНФОРМАЦИОННЫХ СИСТЕМ}

Л. Ю. Бабинцева

Национальная медицинская академия последипломного образования имени П. Л. Шупика

Рассмотрены вопросы роли процедур выявления новой информации в условиях стремительного увеличения количества неструктурированных данных. Представлены характеристики интеграции информационных систем, функционирующих в едином информационном пространстве. Определено, что оценка эффективности интеграции информационных систем в одной проблемной области требует применения двух групп коэффициентов - обобщающих и технологических; выбор родственных информационных систем должен осуществляться при помощи коэфффициентов эмерджентности.

Ключевые слова: информационные технологии, единое информационное пространство, качество оказания медицинской помощи, единая информационная система здравоохранения, комплементарность информационных систем, конгруэнтность информационной системы, эмерджентность информационных систем.

\section{TECHNOLOGICAL ASPECTS QUANTIFY EVALUATION OF THE INTEGRATED WORK INFORMATION SYSTEMS EFFECTIVENESS}

L. Yu. Babintseva

\section{Shupyk National Medical Academy of Postgraduate Education}

\begin{abstract}
It's discussed the role procedures identification of new information question to the rapid increase of unstructured data. It was presented characteristics integrating information systems, operating in an integrated information space. Determined that the evaluation of the effectiveness of integration of information systems in the same areas requiring the use of two groups of characteristics - global and technological; choice of related information systems should be carried out using the emergence coefficient.
\end{abstract}

Key words: information technology, integrated information space, quality of medical care, integrated information health care system, complementarity of information systems, congruence of information system, emergence of information systems.

() Л. Ю. Бабінцева 
Вступ. Сьогодні система охорони здоров'я в Україні нагально потребує послідовних і глибоких інституціональних і структурних перетворень, спрямованих на поліпшення здоров'я населення та задоволення його справедливих потреб у медичній і фармацевтичній допомозі.

Накопичений за останні роки досвід показав, що взаємодія різних систем за відсутності єдиного стандарту повідомлень, що їх об'єднує в єдину розподілену мережу даних, неможлива. Більш того, функціонування підсистеми в рамках інтегральної системи, вочевидь, має принести додаткову важливу інформацію для державного та регіонального управління. Проте, на жаль, вкрай мало наукових досліджень, присвячених визначенню умов виникнення емерджентності механістичної чи направленої інтеграції інформаційних систем (IC).

Перш за все необхідне визначення технологічних аспектів отримання кількісних характеристик спільного функціонування декількох інформаційних систем, особливо в галузі охорони здоров'я, оскільки їі головною метою є забезпечення якості надання медичної допомоги та загалом здоров'я населення, а їхня робота здійснюється в одному інформаційному просторі.

Мета роботи: визначення характеристик інтеграції інформаційних систем, що функціонують в єдиному інформаційному просторі.

Матеріали та методи дослідження. Проведено ретроспективне дослідження даних літератури, матеріалів систематичних оглядів. Застосовано методи експертних оцінок, ретроспективного аналізу та метааналізу.

Результати та їх обговорення. Розглянемо функціонування інформаційних систем в єдиному інформаційному просторі. Раніше для визначення кількісних характеристик їхньої взаємодії нами було розроблено дві групи коефіцієнтів - узагальнюючі та технологічні $[1,2]$.

До узагальнюючих віднесли такі коефіцієнти:

1) коефіцієнт комплементарно сті $\left(K_{c}\right)$, що представляє відношення запитів на цільову інформацію 3 іншої системи до загальної кількості запитів;

2) коефіцієнт симетричності звернень між системами $\left(\mathrm{K}_{\mathrm{s}}\right)$, що представляє відношення сумарних звернень від однієї системи до другої.

До основних технологічних:

1) коефіцієнт рівномірності звернень від регіонів $\left(\mathrm{A}_{\mathrm{r}}\right)$, що дорівнює відношенню середньоквадратичного відхилення звернень до загальної кількості звернень;
2) коефіцієнт часової асиметрії $\left(\mathrm{A}_{t}\right)$, що дорівнює відношенню середньоквадратичного відхилення звернень до загальної кількості звернень.

Також було визначено й додаткові технологічні коефіцієнти: коефіцієнт кластерного інформаційного «навантаження» на групи критеріїв, що містяться в системах; коефіцієнт точкового інформаційного «навантаження» на окремі критерії, що містяться в системах; коефіцієнт адекватного наповнення інформацією, що забезпечує співставлення своєчасності внесення аналогічних показників до обох систем тощо. Практичне застосування запропонованих коефіцієнтів проілюстровано на прикладі взаємодії двох інформаційних систем - єдиної системи охорони здоров'я та єдиної системи управління обігом лікарських засобів (ЛЗ).

Інформаційна система управління обігом лікарських засобів (ІСУОЛЗ) функціонує як самостійна інформаційна підсистема єдиної інформаційної системи охорони здоров'я (ЄICO3) та забезпечує автономізацію: ведення реєстру ЛЗ, виробів медичного призначення та медичної техніки, дозволених до застосування в Україні; персоніфікований облік призначення пацієнтам ЛЗ у процесі надання медичної допомоги; персоніфікований облік відпуску Л3 в аптечній мережі; облік закупівель та раціонального використання Л3, медичної техніки та виробів медичного призначення на всіх рівнях надання медичної допомоги. Важливими функціями також є облік інформації про побічну дію ЛЗ; моніторинг цін; моніторинг імпорту/експорту ЛЗ і виробів медичного призначення.

Функціонування підсистеми ICУОЛЗ у рамках ЄICO3 має надавати додаткову важливу інформацію для державного та регіонального управління, тому нами сформульовано основні принципи системного регулювання фармацевтичного сектору щодо обігу ЛЗ (табл. 1).

Взаємодія двох IC, гармонізація та комплементарність їхньої роботи може бути забезпечена різними шляхами. Доведено, що забезпечення якісного надання медичної допомоги можливо лише при гарантуванні сумісності та взаємодії ІСУОЛЗ iз СICO3 та іншими суміжними системами.

Слід зауважити, що сумісність і взаємодія однієї системи, яка функціонує із суміжними системами, забезпечуються за рахунок дотримання єдиних організаційних, методологічних і програмно-технічних принципів, у першу чергу, шляхом уніфікації значень показників, що включаються у відомості про об'єкти обліку, на основі застосування єдиних 
Основні принципи системного регулювання фармацевтичного секторущодо обігу Л3

\begin{tabular}{|c|c|c|}
\hline $\begin{array}{c}\text { Група } \\
\text { принципів }\end{array}$ & Зміст принципів & $\begin{array}{c}\text { Кількісна перевірка } \\
\text { впровадження принципів } \\
\text { системного регулювання }\end{array}$ \\
\hline Стратегічні & $\begin{array}{c}\text { Надання додаткової необхідної інформації для дер- } \\
\text { жавного та регіонального управління. Визначення } \\
\text { ступеня використання ЛЗ у різних регіонах при їх } \\
\text { наявності у сховищах }\end{array}$ & Критерії обсягів інформації \\
\hline Технологічні & Наявність декількох джерел інформації & Критерії обсягів інформації \\
\hline Коммунікаційні & $\begin{array}{c}\text { Забезпечення комплементарно сті та конгруентності } \\
\text { інформаційних систем }\end{array}$ & $\begin{array}{c}\text { Критерії комплементарно сті. } \\
\text { Критерії конгруентності }\end{array}$ \\
\hline Соціальні & Моніторинг забезпечення населення Л3 & $\begin{array}{c}\text { Кількість скарг населення та } \\
3 \mathrm{O} 3\end{array}$ \\
\hline
\end{tabular}

класифікаторів і довідників, а також застосування для інформаційної взаємодії з суміжними інформаційними системами єдиних протоколів телекомунікаційних мереж, форм документів і форматів даних, що передаються на електронних носіях.

Нам представлялося важливим визначити показники використання ЛЗ у різних регіонах при їх наявності у сховищах, що надасть управлінську інформацію відносно інформаційного забезпечення та місцевої логістики. Також важливими відомостями стають порівняння ефективності використання ЛЗ, якщо врахувати розповсюдження генериків і оригінальних ЛЗ.

Аналіз статистичних даних щодо застосування двох систем виявив декілька дивних фактів. Перший пов'язаний із великим розкидом даних по різним регіонам України. Коефіцієнт варіації для більшості перелічених показників перевищував 85-90\%.

Більш того, виявилося, що більшість інформаційних систем не веде статистику запитів лікарів до них. Хоча, на нашу думку, надзвичайну цінність мають складати дані про запити на отримання довідкової інформації відносно переліку пільговиків, їхнього відношення до затвердженого в країні регістру про осіб, які страждають рідкісними (орфаними) захворюваннями, про нормативні документи щодо формування заявок на лікарські засоби, запити про нормативно-методичну допомогу (наприклад, ознайомлення 3 наказами Міністерства охорони здоров'я щодо організації роботи 3 первинної облікової медичної документації), статистика захворюваності в регіоні тощо.

Єдиними значущими (по частоті) запитами були: аналітичні огляди 3 питань застосування стандартів, термінів, понять, що використовуються в світовій охороні здоров'я, матеріали 3 доказової медицини.

Для визначення кількісних характеристик змін у закладах охорони здоров'я (3О3) нами також запропоновано показник продуктивності, під яким розуміли зменшення негативного впливу фактору, що аналізується, а завдяки йому визначення ступеня здатності IC виконувати свою функцію. Зміни кількісно представляли як математичне очікування показників, що аналізувалися.

В ході статистичних досліджень отримано попередні результати, що свідчать про підвищення ефективності функціонування системи протягом трьох років на $11 \pm 1,7 \%$, а продуктивності - на $7 \pm 2 \%$. Зокрема, в результаті експерименту визначено, що застосування ІСУОЛЗ сприяє підвищенню якості медичної допомоги. Діагностичні та лікувальні помилки, неточності ранньої та диференціальної діагностики захворювань зменшилися на $11,3+2,2 \%$.

Слід взяти до уваги, що новітня апаратура формує звіти в електронному вигляді (відеоінформація, фотографії, сканінформація тощо). При цьому, для лікарів важливо мати інструмент швидкого пошуку, доступу до клінічної інформації, у тому числі, про застосування Л3, швидкого пошуку необхідних генериків та їхнього резервного зберігання, а також мати можливості для попереднього швидкого експрес-аналізу отриманої інформації. Все це надають запропоновані інформаційні системи.

їхн інтегральна робота має ряд нових властивостей. Нами визначено характеристики емерджентно сті спільного функціонування двох систем, що викликані властивостями неадитивних характеристик частин системи, нелінійністю зв'язків 
між характеристиками систем та їх компонентів. Оскільки безпосередньо емерджентні характеристики вимірювати досить складно, використовуються частіше їх непрямі прояви. Отже, емерджентні властивості об'єднаної системи оцінювали через

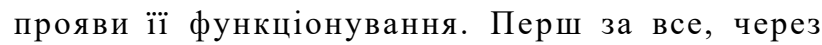
можливість майбутнього функціонування, покликаного забезпечити довгострокову роботу системи. Довгострокова ефективність означає, що обрані поточні рішення повинні задовольняти майбутні потреби користувачів. Позиціонування системи на задоволення майбутніх потреб базувалося на її проактивності.

До основних характеристик емерджентно сті віднесли: 1) характеристики сталої емерджентності, що віддзеркалюють постійне зростання нових (неочікуваних) запитів; 2) показники ефективності спільного функціонування створених систем.

Важливим завданням виявилося підвищення ефективності пошуку нових знань із накопичених у різних інформаційних системах. Воно виникло 3 декількох причин. Так, після застосування традиційних методів аналізу, будь-то пов'язаного 3 аналізом перебігу хвороби та передбачуваного лікування або дослідження ефективності роботи медичного закладу, перед практичними лікарями (провізорами) встає завдання обгрунтування нових підходів до подальшого покращення якості надання медичної допомоги. Для цього корисним може бути застосування накопиченого досвіду.

Проблема виявлення нового знання (ВНЗ) в сховищах медичних даних, що в англомовній літературі визначається як - knowledge discovery in databases (KDD) - і основного етапу цього процесу виявлення та дослідження даних (data mining), одна 3 найважливіших при створенні сучасних інтелектуальних медичних інформаційних систем (MIC).

Традиційні методи аналізу медичної інформації людиною не справляються з усе зростаючими потоком і обсягом накопиченої медичної інформації, iii аналіз став вузьким місцем, стримуючим подальший розвиток досліджень і надання практичної медичної допомоги. Засоби KDD надають допомогу аналітикам у знаходженні прихованих залежностей у даних і можуть значно скоротити час, необхідний для аналізу даних. Одержувані моделі можна використовувати як для передбачення майбутніх значень будь-яких показників, так і для аналізу, опису за допомогою точної моделі поточного стану досліджуваного об'єкта. Побудова нової моделі, це тільки один крок у процесі знаходження нового знання. Для оцінювання корисності видобутого знання необхідно перевірити побудовану модель на практиці, в реальному світі, порівнявши результати iii застосування 3 результатами традиційно прийнятих рішень. Саме в такому разі стає в нагоді використання декількох інформаційних систем.

Виявлення інформації $є$ різновидом інформаційного оброблення матеріалу, при якому із зовні не пов'язаної інформації можна виявити логічні закономірності.

В сучасних інформаційних технологіях (IT) роль такої процедури, як виявлення інформації, все більше зростає через стрімке збільшення кількості неструктурованої інформації, зокрема, в Інтернеті. Ця інформація може бути зроблена більше структурованою за допомогою перетворення в реляційну форму або додаванням XML розмітки.

Два підходи - статистичний і нейромережевий започаткували два досить різні за своїми методами та цілями класи систем інтелектуального аналізу баз даних. Можна сказати, що окремі статистичні методи є як би знаряддями нижчого рівня в порівнянні з методами виявлення знань (МВ3). Методи виявлення знань користуються статистичними методами, комбінуючи їх у стандартних схемах рішення типових завдань. Загальна концепція МB3 - мінімізувати втручання людини, зробити аналіз по можливості більше автоматичним.

Більшість із існуючих методів виявлення знань використовують в якості окремих, елементарних операцій класичних статистичних методів.

Метод мультилінійної регресії з автоматичним вибором незалежних змінних дозволяє обрати 3 великої кількості наявних незалежних параметрів найбільш важливі, що результативно впливають на задану змінну. Фактично, цей метод у рамках деякої схеми застосування використовує стандартний метод лінійної регресії, тим самим дозволяючи значно менше апріорі знати про шукану модель.

Другий тип завдань - завдання опису наявних даних, виявлення в них залежностей із метою їх осмислення дослідником. Цей клас завдань включає: знаходження функціональних зв'язків між різними показниками та змінними у формі, що інтерпретується людиною; кластеризації симптомів, станів і захворювань; виділення «виключень» iз зібраних даних, а також інтеграцію отриманих даних.

Якщо розглядати перший клас завдань, то зазвичай говорячи про функціональну залежність, 
мають на увазі залежності між безперервними числовими змінними.

Можна також розглядати залежності, що включають звичайні числові, булеві функції (типу «так/ ні») і категоріальні змінні (нечислові параметри, скажімо, діагнози хвороб, що можуть бути закодовані).

При другому класі завдань є деякий набір описів об'єктів. Часто ці об'єкти не складають деякої єдиної маси, а природним чином розбиваються на будь-які групи. Наприклад, група пацієнтів, які страждають легеневими захворюваннями, дерматитами або розладом опорно-рухової системи. Необхідно ж виділити природні групи, або кластери, на основі наявної у базі даних інформації. Інтерпретація отриманої інформації може виявити чіткий медичний сенс, і нам було б цікаво зрозуміти, що означає таке групування точок і з чим воно пов'язане. Відмітимо також, що в проблемах дослідження організації медичної допомоги населенню знання розбиття всієї безлічі пацієнтів на деякі характерні групи може допомогти правильно організувати роботу медичного закладу.

У третьому класі завдань, що відноситься до опису виключень, виняткових ситуацій, записів (наприклад, окремих пацієнтів), що різко відрізняються чим-небудь від основної безлічі записів (групи хворих). Знання виключень може бути використане двояким чином. Можливо, ці записи утворюють собою випадковий збій, наприклад, помилки операторів, що вводили дані в комп'ютер. Подібну «шумову», випадкову складову має сенс виключити з подальших досліджень. 3 іншого боку, окремі, виняткові записи можуть представляти самостійний інтерес для дослідження, оскільки вони можуть вказувати на рідкісні, але важливі аномальні захворювання. Навіть сама ідентифікація цих записів, не говорячи про їхній подальший аналіз і детальний розгляд, може виявитися дуже корисною для розуміння суті об'єктів або явищ, що вивчаються.

Нарешті, останній четвертий різновид завдань, що включається в даний клас інтелектуального аналізу даних, визначає підсумкову характеристику даних. Узагальнені дані - це знаходження будь-яких фактів, що вірні для всіх або майже всіх записів у вибірці даних, що вивчається, але які досить рідко зустрічалися.

Підкреслимо, що для здійснення визначених процедур необхідні два етапи, які передують аналізу даних методами ВНЗ.
Перший із них полягає в приведенні даних до форми, придатної для застосування конкретних математичних підходів, у тому числі побудова автоматичних рубрикаторів, класифікаторів симптомів, хвороб і так далі. Практично жодна 3 існуючих систем ВНЗ не може працювати безпосередньо 3 текстами. Відповідно, потрібні деякі похідні параметри, що відображають аналізований текст: частота зустрічі ключових слів, параметри, що характеризують сполучуваність тих або інших слів у реченні тощо.

Другий полягає у виборі такої додаткової інформаційної системи, де коефіцієнт емерджентності вище .

\section{Висновки.}

1. Процедури інтеграції інформаційних систем, що використовують інформацію однієї проблемної області потребують застосування двох груп коефіцієнтів - узагальнюючих і технологічних.

2. Вибір споріднених інформаційних систем має здійснюватися за допомогою коефіцієнтів емерджентно сті.

\section{Література.}

1. Бабінцева Л. Ю. Кількісне оцінювання ефективності спільного використання різних інформаційних систем при їх інтеграції у рамках єдиного комплексу завдань / Л. Ю. Бабінцева // Медична інформатика та інженерія. - 2015. - № 2 (30). - С. 35-40.

2. Бабінцева Л. Ю. Кількісні характеристики комплементарності єдиної інформаційної системи охорони здоров'я та інформаційної системи управління обігом лікарських засобів / Л. Ю. Бабінцева // Медична інформатика та інженерія. - 2014. - № 4. - С. 35-38.

3. Мінцер О. П. Про перспективи ширшого використання понять комплементарно сті та конгруентності в практичній медицині / О. П. Мінцер, Л. Ю. Бабінцева // Медична інформатика та інженерія. - 2015. - № 3 (31). - С. 5-8.

4. Концепція інформатизації охорони здоров'я України / Мінцер О. П., Вороненко Ю. В., Бабінцева Л. Ю., Банчук М. В. та інш. // Медична інформатика та інженерія. 2012. - № 3. - С. 5-29.

5. Мінцер О. П. Засади створення єдиної державної системи інформаційного забезпечення закладів охорони здоров'я / Мінцер О. П., Бабінцева Л. Ю., Банчук М. В. // Медична інформатика та інженерія. - 2011. - № 3. C. 5-12.

6. Василенко А. М. Комплементарная медицина в современном здравоохранении / Василенко А. М., Шарипова М. М., Лузина К. Э. // Вестник Росздравнадзора. - 2011. - № 2. - С. 67-72. 


\section{References.}

1. Babintseva, L.Yu. (2015) Kil'kisne otsinyuvannya efektyvnosti spil'noho vykorystannya riznykh informatsiynykh system pry yikh intehratsiyi u ramkakh yedynoho kompleksu zavdan' [Efficient sharing quantitative estimates of various information systems at their integration under a single set of tasks]. Medychna informatyka ta inzheneriya (Medical Informatics and Engineering), 2 (30), 35-40 [In Ukrainian],

2. Babintseva, L.Yu. (2014) Kil'kisni kharakteiystyky komplementarnosti yedynoyi informatsiynoyi systemy okhorony zdorov'ya ta informatsiynoyi systemy upravlinnya obihom likars'kykh zasobiv [Quantitative characteristics of complementary integrated health care system and integrated medication management information system]. Medychna informatyka ta inzheneriya (Medical Informatics and Engineering), 4, 35-38 [In Ukrainian].

3. Mintser, O.P., Babintseva, L.Yu. (2015) Pro perspektyvy shyrshoho vykorystannya ponyat' komplementarnosti ta konhruentnosti $\mathrm{v}$ praktychniy medytsyni [Prospects wider use of the concept of complementarity and congruence in practical medicine]. Medychna informatyka ta inzheneriya
(Medical Informatics and Engineering), 3 (31), 5-8 [In Ukrainian].

4. Mintser, O.P., Voronenko, Yu.V., Babintseva, L.Yu., at all (2012) Kontseptsiya informatyzatsiyi okhorony zdorov»ya Ukrayiny [Conception of informatization of health care of Ukraine]. Medychna informatyka ta inzheneriya (Medical Informatics and Engineering), 3, 5-29 [In Ukrainian].

5. Mintser, O.P., Babintseva, L.Yu., Banchuk, M.V. (2011) Zasady stvorennya yedynoyi derzhavnoyi systemy informatsiynoho zabezpechennya zakladiv okhorony zdorov»ya [Principles of formation of unified state system of informative providing of health care institutions]. Medychna informatyka ta inzheneriya (Medical Informatics and Engineering), 3, 5-12 [In Ukrainian].

6. Vasilenko, A.M., Sharipova, M.M., Luzina, K.E. (2011) Komplementarnaya medytsyna $v$ sovremennom zdravookhranenyy [Complementary medicine in the modern health care]. Vestnyk Roszdravnadzora (Bulletin of Roszdravnadzor), 2, 67-72 [In Russian]. 